Charles R. Berger (Ed.)

Interpersonal Communication 


\section{Handbooks of Communication Science}

Edited by

Peter J. Schulz and Paul Cobley

Volume 6 


\section{Interpersonal Communication}

Edited by

Charles R. Berger 


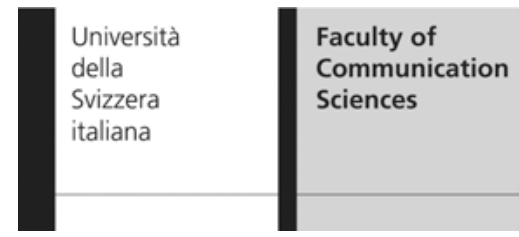

The publication of this series has been partly funded by the Università della Svizzera italiana - University of Lugano.

ISBN 978-3-11-027642-8

e-ISBN 978-3-11-027679-4

Library of Congress Cataloging-in-Publication Data

A CIP catalog record for this book has been applied for at the Library of Congress.

Bibliographic information published by the Deutsche Nationalbibliothek The Deutsche Nationalbibliothek lists this publication in the Deutsche Nationalbibliografie; detailed bibliographic data are available in the Internet at http://dnb.dnb.de.

(C) 2014 Walter de Gruyter GmbH, Berlin/Boston Cover image: Oliver Rossi/Photographer's Choice RF/Gettyimages Typesetting: Meta Systems Publishing \& Printservices GmbH, Wustermark Printing and binding: CPI buch bücher.de $\mathrm{GmbH}$, Birkach (2) Printed on acid-free paper Printed in Germany

www.degruyter.com 